\title{
Crystal Structure and Catalytic Activity of A Novel Cd(II) Coordination Polymer Formed by Dicarboxylic Ligand
}

\author{
Zhi-Xiang Ji ${ }^{*}$, Peng-Fei Li ${ }^{2}$ \\ ${ }^{1}$ College of Information and Engineering, Weifang University, Weifang 261061, P.R. China \\ ${ }^{2}$ College of Chemical Engineering, Qingdao University of Science and Technology, \\ Qingdao 266061, P.R. China
}

Received: 25th April 2017; Revised: 11st September 2017; Accepted: 1st November 2017; Available online: 11 $1^{\text {st }}$ June 2018; Published regularly: 1st August 2018

\begin{abstract}
A new $\mathrm{Cd}(\mathrm{II}) \quad$ coordination polymer, $\left\{\left[\mathrm{Cd}_{3}(\mathrm{~L})_{2}(\mathrm{DMF})_{2}\left(\mathrm{H}_{2} \mathrm{O}\right)_{2}\right] \cdot \mathrm{H}_{2} \mathrm{O}\right\} \mathrm{n} \quad\left(\mathrm{H}_{2} \mathrm{~L} \quad=\quad\right.$ 1,3-bisbenzyl-2imidazolidine-4,5-dicarboxylic acid) was synthesized by one-pot synthesis method from 1,3-bisbenzyl-2imidazolidine-4,5-dicarboxylic acid, $\mathrm{NaOH}, \mathrm{DMF}$, and $\mathrm{Cd}\left(\mathrm{NO}_{3}\right)_{2} \cdot 4 \mathrm{H}_{2} \mathrm{O}$. Its structure was determined by elemental analysis and single crystal X-ray diffraction. Structural analysis shows that three Cd(II) ions are all six-coordinated with four oxygen atoms of four 1,3-bisbenzyl-2-imidazolidine-4,5-dicarboxylate ligands and two $\mathrm{O}$ atoms from two DMF molecules (Cd1) or two oxygen atoms of two coordinated $\mathrm{H}_{2} \mathrm{O}$ molecules (Cd2 and Cd3) to form an octahedral coordination geometry. The $\mathrm{Cd}(\mathrm{II})$ coordination polymer displays a 1D chained structure by the bridging carboxylate groups from 1,3-bisbenzyl-2-imidazolidine4,5-dicarboxylate ligands. The conversion of benzaldehyde is $90.9 \%$, which is $40 \sim 50 \%$ higher than those of the other three aldehydes (4-methylbenzaldehyde, $p$-methoxybenzaldehyde and 3chlorobenzaldehyde), so the Cd(II) coordination polymer catalyst shows better catalytic activity for the coupling reaction of benzaldehyde, phenylacetylene, and piperidine than the other three aldehydes. Copyright $\odot 2018$ BCREC Group. All rights reserved
\end{abstract}

Keywords: 1,3-Bisbenzyl-2-imidazolidine-4,5-dicarboxylic acid; Cd(II) coordination polymer; Synthesis; Structural characterization; Catalytic property

How to Cite: Ji, Z.X., Li, P.F. (2018). Crystal Structure and Catalytic Activity of A Novel Cd(II) Coordination Polymer Formed by Dicarboxylic Ligand. Bulletin of Chemical Reaction Engineering \& Catalysis, 13 (2): 220-226 (doi:10.9767/bcrec.13.2.1178.220-226)

Permalink/DOI: https://doi.org/10.9767/bcrec.13.2.1178.220-226

\section{Introduction}

Many studies show that the metal-organic coordination polymer materials have attracted wide interests among chemists because of their structural diversities and potential applications in many fields such as antitumor and antibacterial activities [1-5], luminescent properties [69], catalytic activities [10-12], magnetic proper-

* Corresponding Author.

E-mail: sysjzx@126.com (Z.X. Ji),

Telp: +86-536-8785613, Fax: +86-536-8785613 ties [13-16], DNA-binding properties [17,18], and gas adsorption [19,20], and so on.

Owing to the abundant coordination modes, the ligands containing carboxylate group have occupied an important role in the construction of metal-organic coordination polymer materials [21-27]. However, so far, the researches on the catalytic property of $\mathrm{Cd}$ (II) complexes are less. Our research group has carried on the studies on the synthesis, novel structure and property of metal-organic coordination polymer materials $[28,29]$. 
As part of our studies, in this paper, we have synthesized a novel $\mathrm{Cd}$ (II) coordination polymer by one-pot synthesis method from 1,3bisbenzyl-2-imidazolidine-4,5-dicarboxylic acid, $\mathrm{NaOH}, \quad \mathrm{DMF}$ and $\mathrm{Cd}\left(\mathrm{NO}_{3}\right)_{2} \cdot 4 \mathrm{H}_{2} \mathrm{O}$. And its structure has been determined by elemental analysis and X-ray single crystal diffraction. The catalytic activities for the coupling reaction of aldehydes (benzaldehyde, $p$-tolualdehyde, $p$ anisaldehyde and $m$-chlorobenzaldehyde), phenylacetylene, and piperidine with 1,4dioxane as solvent at $120^{\circ} \mathrm{C}$ for $12 \mathrm{~h}$ have been investigated. Interestingly, the $\mathrm{Cd}(\mathrm{II})$ coordination polymer catalyst shows better catalytic activity for the coupling reaction of benzaldehyde, phenylacetylene, and piperidine than the other three aldehydes.

\section{Materials and Methods}

\subsection{Materials and measurements}

1,3-Bisbenzyl-2-imidazolidine-4,5-dicarboxylic acid, $\mathrm{NaOH}, \mathrm{DMF}, \mathrm{Cd}\left(\mathrm{NO}_{3}\right)_{2} \cdot 4 \mathrm{H}_{2} \mathrm{O}$, and solvent used were reagent grade and purchased from Jinan Henghua Chemical Reagent Company. Element analyses (C, H and N) were carried out with an Elementar Vario III EL elemental analyzer (Hanau, Germany). The single crystal data of $\mathrm{Cd}$ (II) coordination polymer

Table 1. Crystallographic data and structure refinement for $\mathrm{Cd}(\mathrm{II})$ coordination polymer

\begin{tabular}{|c|c|}
\hline Empirical formula & $\mathrm{C}_{44} \mathrm{H}_{50} \mathrm{Cd}_{3} \mathrm{~N}_{6} \mathrm{O}_{14}$ \\
\hline Formula weight & 1111.70 \\
\hline Temperature/K & $293(2)$ \\
\hline Crystal system & Monoclinic \\
\hline Space group & $C 2 / c$ \\
\hline$a / \AA$ & $28.053(6)$ \\
\hline$b / \AA$ & $10.956(2)$ \\
\hline$c / \AA$ & 31.933(6) \\
\hline$a /^{\circ}$ & 90 \\
\hline$\beta /^{\circ}$ & 111.04(3) \\
\hline$\gamma /{ }^{\circ}$ & 90 \\
\hline Volume/Å3 & $9160(3)$ \\
\hline$Z$ & 8 \\
\hline$\rho_{\text {calc }}, \mathrm{mg} / \mathrm{mm}^{3}$ & 1.612 \\
\hline$\mu / \mathrm{mm}^{-1}$ & 1.002 \\
\hline$S$ & 1.025 \\
\hline$F(000)$ & 4512 \\
\hline Index ranges & $\begin{array}{l}-33 \leq h \leq 33 \\
-13 \leq k \leq 12 \\
-37 \leq l \leq 37\end{array}$ \\
\hline Reflections collected & 33741 \\
\hline$\theta /{ }^{\circ}$ & $3.07-25.01$ \\
\hline Independent reflections & $7967[R(\mathrm{int})=0.1681]$ \\
\hline Data/restraints/parameters & $7967 / 0 / 596$ \\
\hline Goodness-of-fit on $F^{2}$ & 1.025 \\
\hline Refinement method & $\begin{array}{l}\text { Full-matrix least-squares } \\
\text { on F2 }\end{array}$ \\
\hline Final $R$ indexes [I>=2o(I)] & $R_{1}=0.0529, w R_{2}=0.0624$ \\
\hline Final $R$ indexes [all data] & $R_{1}=0.1294, w R_{2}=0.0800$ \\
\hline Largest diff. peak/hole / e $\AA^{-3}$ & $1.207 /-1.604$ \\
\hline
\end{tabular}

were obtained by means of a Bruker Smart CCD diffractometer (Bruker, Billerica, MA, USA).

\subsection{Synthesis of $\mathrm{Cd}$ (II) coordination poly- mer}

The 1,3-bisbenzyl-2-imidazolidine-4,5dicarboxylic acid ligand (1.0 mmol, $0.3544 \mathrm{~g}$ ) and $\mathrm{NaOH}$ (4.0 mmol, $0.160 \mathrm{~g}$ ) were dissolved in $10 \mathrm{~mL}$ ethanol solution. A white precipitate formed immediately when $\mathrm{Cd}\left(\mathrm{NO}_{3}\right)_{2} \cdot 4 \mathrm{H}_{2} \mathrm{O}(0.5$ mmol, $0.1543 \mathrm{~g}$ ) was added to the above solution. Then 5.0 mL DMF was added and the precipitate dissolved. The reactants were continuously stirred at $c a .70{ }^{\circ} \mathrm{C}$ for $5 \mathrm{~h}$. The resultant solution was filtered and left aside for crystallization at room temperature. The colorless block crystals appeared for 20 days (56\% yield). Elemental analysis (\%) calculated for $\mathrm{C}_{44} \mathrm{H}_{50} \mathrm{Cd}_{2} \mathrm{~N}_{6} \mathrm{O}_{14}: \mathrm{C}, 47.49 ; \mathrm{H}, 4.50 ; \mathrm{N}, 7.56$. Found (\%): C, 47.58; H, 4.29; N, 7.41.

\subsection{Crystal structure determination}

The colorless block single crystal of $\mathrm{Cd}$ (II) coordination polymer $(0.21 \times 0.20 \times 0.18 \mathrm{~mm})$ was measured on a Bruker Smart APEX CCD diffractometer with graphite-monochromated Mo- $K a$ radiation $(\lambda=0.71073 \AA)$ at $293(2) \mathrm{K}$. The structure was solved by direct method using SHELXS-97 program [30] and refined by full-matrix least squares on $F^{2}$ by means of the program SHELXL-97 [30]. The crystallographic data and processing parameters for $\mathrm{Cd}(\mathrm{II})$ coordination polymer are summarized in Table 1.

\subsection{General procedure for the three com- ponent coupling reaction $\left(\mathrm{A}^{3}\right)$}

The $\mathrm{A}^{3}$ coupling reactions of aldehyde $(0.13$ $\mathrm{mmol})$, piperidine $(0.15 \mathrm{mmol}, 12.8 \mathrm{mg})$, phenylacetylene $(0.17 \mathrm{mmol}, 16.9 \mathrm{mg}), 1,4$ dioxane (1.5 g) using $\mathrm{Cd}(\mathrm{II})$ coordination polymer (40 mg) as catalyst were stirred for $12 \mathrm{~h}$ at $120{ }^{\circ} \mathrm{C}$. After completion of the reaction, the mixtures were cooled to room temperature and the products obtained by centrifugation. The $\mathrm{Cd}(\mathrm{II})$ coordination polymer catalyst was dried at $60{ }^{\circ} \mathrm{C}$ under vacuum for $3 \mathrm{~h}$ and stored in a desiccator for its use in subsequent catalytic runs. The product was analysed by GC ((GC1100 , capillary column SE-54) using $n$-nonane as the external standard. The conversion and selectivity were calculated by Equations (1) and (2), respectively. 
$C_{\text {benzaldehyde }}=\frac{n_{\text {initial }}-n_{\text {after reaction }}}{n_{\text {initial }}} \times 100 \%$

$S=\frac{n_{\text {prop arg yla mine }}}{n_{\text {initial }}-n_{\text {after reaction }}} x 100 \%$

\section{Results and Discussion}

\subsection{Structural description of Cd(II) coordi- nation polymer}

The coordination environment of $\mathrm{Cd}(\mathrm{II})$ ions is shown in Figure 1 and the selected bond lengths and bond angles for $\mathrm{Cd}(\mathrm{II})$ coordination polymer are listed in Table 2 . Structural analysis shows that $\left\{\left[\mathrm{Cd}_{2}(\mathrm{~L})_{2}(\mathrm{DMF})_{2}\left(\mathrm{H}_{2} \mathrm{O}\right)_{2}\right] \cdot \mathrm{H}_{2} \mathrm{O}\right\}_{\mathrm{n}}$ crystallizes in monoclinic $C_{2} / c$ space group, and its asymmetric unit contains two $\mathrm{Cd}$ (II)

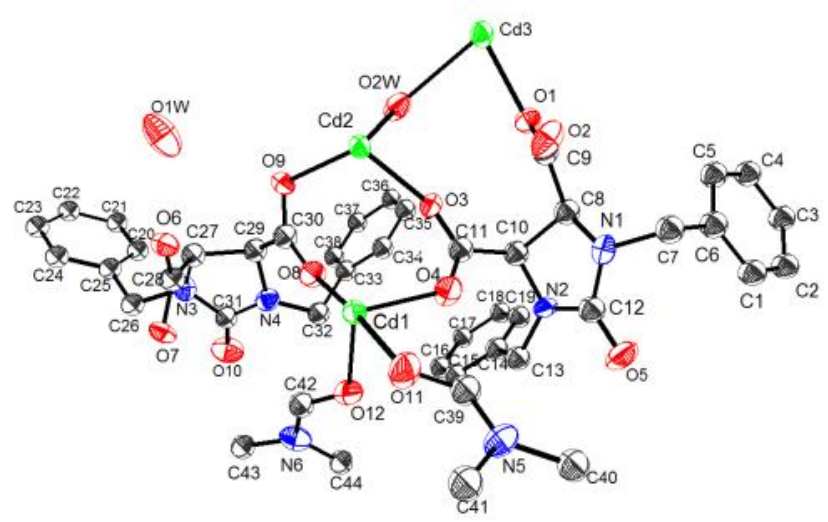

Figure 1. The coordination environment of Cd(II) ion ions, two 1,3-bisbenzyl-2-imidazolidine-4,5dicarboxylate ligands, two DMF molecules, two coordinated water molecules and one lattice water molecule. As shown in Figure 1, Cd1 is six-coordinated by four $\mathrm{O}$ atoms of four bridging carboxylate groups from 1,3-bisbenzyl-2imidazolidine-4,5-dicarboxylate ligands, two $\mathrm{O}$ atoms from two DMF molecules and adopts an octahedral coordination geometry, in which two $\mathrm{O}$ atoms ( $\mathrm{O} 4$ and $\mathrm{O} 6 \mathrm{~A})$ are at the axial positions, and four $\mathrm{O}$ atoms $(\mathrm{O} 8, \mathrm{O} 9 \mathrm{~A}, \mathrm{O} 11$, and O12) are in the equatorial plane with deviation $0.0324 \AA . \mathrm{Cd} 2$ and $\mathrm{Cd} 3$ are also six-coordinated by four $\mathrm{O}$ atoms of four bridging carboxylate groups from 1,3-bisbenzyl-2-imidazolidine-4,5dicarboxylate ligands, two $\mathrm{O}$ atoms from two coordinated water molecules and adopt an octahedral coordination geometry (for $\mathrm{Cd} 2$ : $\mathrm{O} 9$ and $\mathrm{O} 2 \mathrm{~W}$ are at the axial positions, O3, O3A, O9A, and O2WA are in the equatorial plane; for Cd3: $\mathrm{O} 1$ and $\mathrm{O} 1 \mathrm{~A}$ are at the axial positions, $\mathrm{O} 7 \mathrm{~B}, \mathrm{O} 7 \mathrm{C}, \mathrm{O} 2 \mathrm{~W}$ and $\mathrm{O} 2 \mathrm{WA}$ are in the equatorial plane). The $\mathrm{Cd}(\mathrm{II})$ ions are interlinked by the bridging carboxylate groups from 1,3bisbenzyl-2-imidazolidine-4,5-dicarboxylate ligands to form 1D chained structure as shown in Figure 2. In addition, Figure 3 displays a 3D

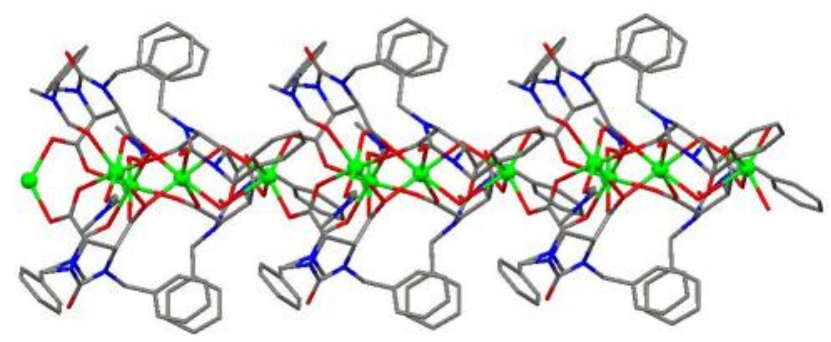

Figure 2. 1D chained structure of Cd(II) coordination polymer by bridging $\mathrm{O}$ atoms

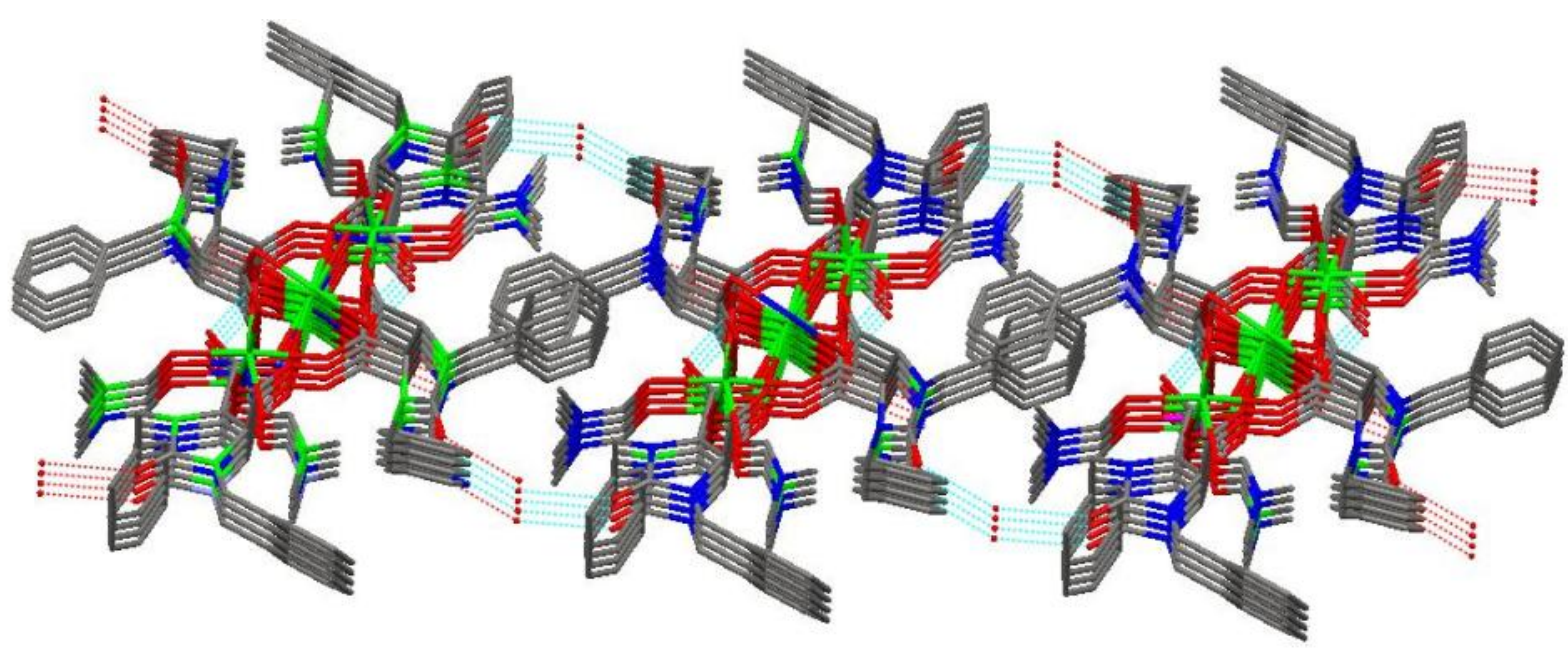

Figure 3. 3D network structure of Cd(II) coordination polymer by hydrogen bonds and $\Pi-\Pi$ stacking 
network structure formed by the 1D chain. And the weak interaction of $\mathrm{O}-\mathrm{H}$... O hydrogen bonds and $\Pi-\Pi$ stacking play an important role in the stability of the network structure. The hydrogen bonds of $\mathrm{Cd}(\mathrm{II})$ coordination polymer are listed in Table 3.

\subsection{Catalytic studies of three component coupling reaction}

The catalytic activities of $\mathrm{Cd}(\mathrm{II})$ coordination polymer catalyst was studied for the synthesis of propargylamines in the $\mathrm{A}^{3}$ coupling reaction (Figure 4). The conversions of aldehydes were given in Table 4 . From the catalytic results, it can be seen that the conversion of benzaldehyde was $90.9 \%$, which shows that the $\mathrm{Cd}$ (II) coordination polymer catalyst shows high catalytic activity for the coupling reaction of benzaldehyde, phenylacetylene, and piperidine with 1,4-dioxane as solvent at $120^{\circ} \mathrm{C}$ for $12 \mathrm{~h}$. The catalyst features $100 \%$ selectivity to the product of propargylamine for the $\mathrm{A}^{3}$ coupling reaction without any byproduct. The reusabil-

Table 2. Selected bond lengths ( $\AA$ ) and bond angles $\left(^{\circ}\right)$ for $\mathrm{Cd}(\mathrm{II})$ coordination polymer (Symmetry codes: (A) $-x, y,-z+3 / 2$; (B) $x, y-1, z$; (C) $-x, y-1,-z+3 / 2$ )

\begin{tabular}{|c|c|c|c|}
\hline Bond & $d$ & Angle & $\left({ }^{\circ}\right)$ \\
\hline $\mathrm{Cd} 1-\mathrm{O} 4$ & $2.209(4)$ & O4-Cd1-O6A & $174.27(17)$ \\
\hline $\mathrm{Cd} 1-\mathrm{O} 6 \mathrm{~A}$ & $2.250(4)$ & O4-Cd1-O11 & $83.34(16)$ \\
\hline Cd1-O11 & $2.262(4)$ & O6A-Cd1-O11 & $92.33(15)$ \\
\hline Cd1-O8 & $2.298(4)$ & O4-Cd1-O8 & $96.91(16)$ \\
\hline Cd1-O12 & $2.298(4)$ & O8-Cd1-O6A & $87.81(15)$ \\
\hline Cd1-O9A & $2.393(4)$ & O11-Cd1-O8 & 173.57(15) \\
\hline $\mathrm{Cd} 2-\mathrm{O} 3$ & $2.236(4)$ & O4-Cd1-O12 & $93.95(16)$ \\
\hline $\mathrm{Cd} 2-\mathrm{O} 3 \mathrm{~A}$ & $2.236(4)$ & $\mathrm{O} 12$-Cd1-O6A & $90.20(15)$ \\
\hline $\mathrm{Cd} 2-09 \mathrm{~A}$ & $2.288(4)$ & O11 -Cd1-O12 & $95.50(16)$ \\
\hline Cd2-O9 & $2.288(4)$ & O8-Cd1-O12 & $78.06(15)$ \\
\hline $\mathrm{Cd} 2-\mathrm{O} 2 \mathrm{~W}$ & $2.356(4)$ & O4-Cd1-O9A & $92.69(15)$ \\
\hline $\mathrm{Cd} 2-\mathrm{O} 2 \mathrm{WA}$ & $2.356(4)$ & O6A-Cd1-O9A & $84.26(13)$ \\
\hline $\mathrm{Cd} 3-\mathrm{O} 7 \mathrm{~B}$ & $2.235(4)$ & O11-Cd1-O9A & $99.08(15)$ \\
\hline $\mathrm{Cd} 3-\mathrm{O} 7 \mathrm{C}$ & $2.235(4)$ & O8-Cd1-O9A & $87.34(14)$ \\
\hline $\mathrm{Cd} 3-\mathrm{O} 1$ & $2.237(4)$ & O12-Cd1-O9A & $164.58(15)$ \\
\hline Cd3-O1A & $2.237(4)$ & O3-Cd2-O3A & $153.4(2)$ \\
\hline $\mathrm{Cd} 3-\mathrm{O} 2 \mathrm{~W}$ & $2.653(4)$ & O3-Cd2-O9A & $94.58(14)$ \\
\hline \multirow[t]{19}{*}{$\mathrm{Cd} 3-\mathrm{O} 2 \mathrm{WA}$} & $2.653(4)$ & O3A-Cd2-O9A & $103.60(14)$ \\
\hline & & O3-Cd2-O9 & $103.60(14)$ \\
\hline & & O3A-Cd2-O9 & $94.58(14)$ \\
\hline & & O9-Cd2-O9A & $93.8(2)$ \\
\hline & & O3-Cd2-O2WA & $86.53(14)$ \\
\hline & & O2WA-Cd2-O3A & $73.07(14)$ \\
\hline & & O9A-Cd2-O2WA & $94.05(14)$ \\
\hline & & O9-Cd2-O2WA & $166.67(13)$ \\
\hline & & O3-Cd2-O2W & $73.07(14)$ \\
\hline & & $\mathrm{O} 3 \mathrm{~A}-\mathrm{Cd} 2-\mathrm{O} 2 \mathrm{~W}$ & $86.53(14)$ \\
\hline & & O9A-Cd2-O2W & $166.67(13)$ \\
\hline & & O9-Cd2-O2W & $94.05(14)$ \\
\hline & & $\mathrm{O} 2 \mathrm{WA}-\mathrm{Cd} 2-\mathrm{O} 2 \mathrm{~W}$ & $80.5(2)$ \\
\hline & & O7B-Cd3-O7C & $125.3(2)$ \\
\hline & & O7B-Cd3-O1 & $92.01(15)$ \\
\hline & & O7C-Cd3-O1 & $99.14(15)$ \\
\hline & & O7B-Cd3-O1A & $99.14(15)$ \\
\hline & & O7C-Cd3-O1A & $92.01(15)$ \\
\hline & & O1A-Cd3-O1 & $155.6(2)$ \\
\hline
\end{tabular}


ity of $\mathrm{Cd}(\mathrm{II})$ coordination polymer catalyst was investigated in the $\mathrm{A}^{3}$ coupling reaction of benzaldehyde, phenylacetylene, and piperidine in 1,4-dioxane at $120^{\circ} \mathrm{C}$. The result of recyclability of $\mathrm{Cd}(\mathrm{II})$ coordination polymer catalyst in $\mathrm{A}^{3}$ coupling reaction of benzaldehyde, phenylacetylene, and piperidine was listed in Table 5. In four successive cycles, the conversion of benzaldehyde was $90.9 \%, 72.6 \%, 52.6 \%$, and $46.1 \%$ at $120{ }^{\circ} \mathrm{C}$ for $12 \mathrm{~h}$, respectively.

\section{Conclusions}

In summary, we demonstrated that treatment of $\mathrm{Cd}\left(\mathrm{NO}_{3}\right)_{2} \cdot 4 \mathrm{H}_{2} \mathrm{O}$ with 1,3-bisbenzyl-2imidazolidine-4,5-dicarboxylic acid, $\mathrm{NaOH}$ and DMF formed a new $\left\{\left[\mathrm{Cd}_{2}(\mathrm{~L})_{2}(\mathrm{DMF})_{2}\left(\mathrm{H}_{2} \mathrm{O}\right)_{2}\right]\right.$. $\left.\mathrm{H}_{2} \mathrm{O}\right\}_{n}$ coordination polymer. The catalytic activity of $\mathrm{Cd}(\mathrm{II})$ coordination polymer was evaluated for the $\mathrm{A}^{3}$ coupling reactions of aldehyde, piperidine and phenylacetylene with 1,4dioxane as solvent. The $\mathrm{Cd}(\mathrm{II})$ coordination polymer catalyst shows high catalytic activity for the coupling reaction of benzaldehyde, phenylacetylene, and piperidine.

Table 3. Hydrogen bonds data for Cd(II) coordination polymer

\begin{tabular}{cccccc}
\hline Donor-H...Acceptor & D-H & H...A & D...A & D-H...A & Symmetry transformation \\
\hline O1W-H1WB...O10 & 0.96 & 2.06 & $2.905(8)$ & 146 & $\mathrm{x}, \mathrm{y}, \mathrm{z}$ \\
O1W-H1WA...O5 & 0.96 & 2.25 & $2.913(8)$ & 125 & $-1 / 2+\mathrm{x}, 1 / 2+\mathrm{y}, \mathrm{z}$ \\
O2W-H2WA...O3 & 0.95 & 2.29 & $2.735(6)$ & 108 & \\
O2W-H2WB...O2 & 0.86 & 1.74 & $2.578(6)$ & 165 & $-\mathrm{x}, \mathrm{y}, 3 / 2-\mathrm{z}$ \\
\hline
\end{tabular}

Table 4. Coupling of aldehyde, alkyne, and amine catalyzed by $\mathrm{Cd}$ (II) coordination polymer catalyst in dioxane at $120^{\circ} \mathrm{C}$

\begin{tabular}{ccccccc}
\hline Entry & Cat. & $\mathrm{R}^{1}$ & $\mathrm{R}^{2} \mathrm{R}^{3} \mathrm{NH}$ & $\mathrm{R}^{4}$ & Time (h) & Conversion (\%) \\
\hline 1 & $\mathrm{Cd}(\mathrm{II})$ complex & $\mathrm{Ph}$ & piperidine & $\mathrm{Ph}$ & 12 & 90.9 \\
2 & $\mathrm{Cd}(\mathrm{II})$ complex & $4-\mathrm{CH}_{3} \mathrm{C}_{6} \mathrm{H}_{4}$ & piperidine & $\mathrm{Ph}$ & 12 & 35.9 \\
3 & $\mathrm{Cd}(\mathrm{II})$ complex & $4-\mathrm{CH}_{3} \mathrm{OC}_{6} \mathrm{H}_{4}$ & piperidine & $\mathrm{Ph}$ & 12 & 41.3 \\
4 & $\mathrm{Cd}(\mathrm{II})$ complex & $3-\mathrm{ClC}_{6} \mathrm{H}_{4}$ & piperidine & $\mathrm{Ph}$ & 12 & 50.5 \\
\hline
\end{tabular}

Table 5. Recyclability of $\mathrm{Cd}(\mathrm{II})$ coordination polymer catalyst in $\mathrm{A}^{3}$ coupling reaction of benzaldehyde, phenylacetylene, and piperidine

\begin{tabular}{ccccc}
\hline Run & Solvent & Temperature $\left({ }^{\circ} \mathrm{C}\right)$ & Time $(\mathrm{h})$ & Conversion(\%) \\
\hline 1 & 1,4-dioxane & 120 & 12 & $90.9 \%$ \\
2 & 1,4-dioxane & 120 & 12 & $72.6 \%$ \\
3 & 1,4-dioxane & 120 & 12 & $52.6 \%$ \\
4 & 1,4-dioxane & 120 & 12 & $46.1 \%$ \\
\hline
\end{tabular}

$$
\mathrm{R}^{1}-\mathrm{CHO}+\mathrm{R}^{2} \mathrm{R}^{3} \mathrm{NH}+\mathrm{R}^{4}=\mathrm{H} \frac{\begin{array}{l}
\text { dioxane } \\
\text { cat(II) complex }
\end{array}}{=}
$$

Figure 4. $\mathrm{A}^{3}$ coupling reaction of aldehyde, alkyne, and amine catalyzed by $\mathrm{Cd}(\mathrm{II})$ coordination polymer catalyst 


\section{Acknowledgments}

This project was supported by the Science Foundation of Weifang.

\section{References}

[1] Yaghi, O.M. (2016). Reticular Chemistryconstruction, Properties, and Precision Reactions of Frameworks. Journal of the American Chemical Society, 138: 15507-15509.

[2] Yan, K.K., Fujita, M. (2015). A Speedy Marriage in Supramolecular Catalysis. Science, 350: 1165-1166.

[3] Zhang, Y.B., Liu, Q., Jing, H.R., Cai, Y.J., Wang, Q., Li, Y.G. (2017). Synthesis, Characterization, and Antimicrobial Activity of Two Schiff Base Silver(I) Complexes Derived from 4-Carboxybenzaldehyde. Journal of Coordination Chemistry, 70: 1066-1076.

[4] Majumdar, D., Babu, M.S.S., Das, S., Biswas, J.K., Mondal, M., Hazra, S. (2017). Synthesis, X-ray Crystal Structure, Photoluminescent Property, Antimicrobial Activities and DFT Computational Study of Zn(II) Coordination Polymer Derived from Multisite N,O Donor Schiff base Ligand $\left(\mathrm{H}_{2} \mathrm{~L}^{1}\right)$. Journal of Molecular Structure, 1138: 161-171.

[5] Tai, X.S., Zhao, W.H. (2013). Synthesis, Crystal Structure and Antitumor Activity of $\mathrm{Ca}(\mathrm{II})$ Coordination Polymer Based on 1,5Naphthalenedisulfonate. Journal of Inorganic and Organometallic Polymers and Materials, 23: 1354-1357.

[6] Wang, X.P., Han, L.L., Lin, S.J., Li, X.Y., Mei, K., Sun, D. (2016). Synthesis, Structure and Photoluminescence of Three 2D Cd(II) Coordination Polymers Based on Varied Dicarboxylate Ligand. Journal of Coordination Chemistry, 69: 286-294.

[7] Nawrot, I., Czerwińska, K., Machura, B., Kruszynski, R. (2017). Synthesis, Structural Diversity and Luminescent Properties of Cadmium(II) Coordination Assemblies with 2-(2Aminophenyl)-1H-benzimidazole and Pseudohalide Ions. Journal of Luminescence, 181: 103-113.

[8] LaRose, C.J., LaDuca, R.L. (2017). Luminescent Cadmium 1,3-Adamantanedicarboxylate Coordination Polymers with Diverse Topologies Depending on Dipyridylamide Ligands. Inorganica Chimica Acta, 461: 92-101.

[9] He, Y.C., Xu, N., Zheng, X.F., Yu, Y., Ling, B.P., You, J.M. (2017). A Silver(I) Coordination Polymer Luminescent Thermometer. Dyes Pigments, 136: 577-582.

[10] Bagherzadeh, M., Ashouri, F., Đaković, M. (2014). Synthesis, Structural Characterization and Application of a 2D Coordination
Polymer of Mn-terephthalate as a Heterogeneous Catalyst for Olefin Oxidation. Polyhedron, 69: 167-173.

[11] Wang, L.H., Liang, L., Wang, X. (2017). Synthesis, Structural Characterization and Catalytic Activity of $\mathrm{A} \mathrm{Cu}(\mathrm{II})$ Coordination Polymer Constructed From 1,4-Phenylenediacetic Acid and 2,2'-Bipyridine. Bulletin of Chemical Reaction Engineering \& Catalysis, 12(1): 113118.

[12] Farzaneh, F., Moghzi, F., Rashtizadeh, E. (2016). Zn(II) Coordination Polymer as a Bifunctional Catalyst for Biodiesel Production from Soybean Oil. Reaction Kinetics Mechanisms and Catalysis, 118: 509-521.

[13] Cao, X.Y., Yang, D.D., Li, N., Huang, R.D. (2015). Ligands Effect on the Structures of a Series of Coordination Polymers: Syntheses, Structures, Luminescence and Magnetism. Inorganica Chimica Acta, 427: 285-292.

[14] Sharif, S., Şahin, O., Khan, B., Khan, I.U. (2015). Hydrothermal Synthesis, Structural Investigation, and Magnetic Properties of 2-D Layered Lanthanide $(\mathrm{Ln}=\mathrm{Pr}, \mathrm{Eu}, \mathrm{Gd}, \mathrm{Tb}$, and Er) Coordination Polymers Possessing Infinite 1-D Nanosized Cavities. Journal of Coordination Chemistry, 68: 2725-2738.

[15] Liu, Y.L., Chen, F.Y., Di, Y.Q., Cao, J., Di, Y.Y., Zhou, C.S. (2016). Two Coordination Polymers Based on a Flexible Tritopic Pyridyldicarboxylate Ligand: Structures and Magnetic Properties. Zeitschrift fur Anorganische und Allgemeine Chemie, 642: 246249.

[16] Ma, D.Y., Hu, P., Qin, L., Yan, J.J., Lin, W.J., Ding, W.Q., Lu, H.S., Lin, D.T., Sakiyama, H., Liang, F.L. (2016). Synthesis, Characterization, and Magnetic Properties of Two Transition Metal Coordination Polymers Based on 2,5-Furandicarboxylic Acid and $\mathrm{N}$-donor Ligands. Journal of Inorganic and Organometallic Polymers and Materials, 26: 1053-1060.

[17] Liu, L., Zhang, G.M., Zhu, R.G., Liu, Y.H., Yao, H.M., Han, Z.B. (2014). Dinuclear $\mathrm{Cd}(\mathrm{II}), \mathrm{Mn}(\mathrm{II})$ and $\mathrm{Cu}(\mathrm{II})$ Complexes Derived from (Anthraquinone-1-diyl) benzoate: DNA Binding and Cleavage Studies. RSC Advances, 4: 46639-46645.

[18] Lu, J., Sun, Q., Li, J.L., Gu, W., Tian, J.L., Liu, X., Yan, S.P. (2013). Synthesis, Characterization, and DNA-binding of Two New Cd(II) Complexes with 8-[(2Pyridylmethyl)amino]-quinoline. Journal of Coordination Chemistry, 66: 3280-3290.

[19] Shen, J.J., Li, M.X., Wang, Z.X., Duan, C.Y., Zhu, S.R., He, X.S. (2014). Unexpected 4-Fold $[2+2]$ Interpenetration and Polycatenation 
Behaviors in Porous Luminescent Zinc Metalorganic Frameworks Constructed from Flexible 3,5-Bis(4-pyridylmethoxy)benzoate Ligand. Crystal Growth \& Design, 14: 28182830.

[20] Yoon, M.Y., Moon, D.H. (2015). New Zr(IV) Based Metal-organic Framework Comprising a Sulfur-containing Ligand: Enhancement of $\mathrm{CO}_{2}$ and $\mathrm{H}_{2}$ Storage Capacity. Microporous and Mesoporous Materials, 215: 116-122.

[21] Meundaeng, N., Rujiwatra, A., Prior, T.J. (2017). Copper Coordination Polymers Constructed from Thiazole-5-carboxylic Acid: Synthesis, Crystal Structures, and Structural Transformation. Journal of Solid State Chemistry, 245: 138-145.

[22] Chakraborty, P., Mohanta, S. (2017). Syntheses, Crystal Structures, Lone Pair Functionality and Electrospray Ionization Mass Spectral Properties of Trinuclear, Dimer of Trinuclear and Trinuclear-based One-dimensional Systems of Copper(II) and Lead(II). Inorganica Chimica Acta, 455: 70-80.

[23] Mukherjee, G., Biradha, K. (2014). Topological Equivalences Between Coordination Polymer and Cocrystal: A Tecton Approach in Crystal Engineering. Crystal Growth \& Design, 14: 419-422.

[24] Li, T., Huang, X.H., Zhao, Y.F., Li, H.H., Wu, S.T., Huang, C.C. (2012). An Unusual Double T5(2) Water Tape Trapped in Silver(I) Coordination Polymer Hosts: Influence of the Solvent on the Assembly of $\mathrm{Ag}(\mathrm{I})-4,4$ '-bipyridine Chains with Trans-cyclohexanedicarboxylate and Their Luminescent Properties. Dalton Transactions, 41: 12872-12881.
[25] Liu, C.B., Li, Q., Wang, X., Che, G.B., Zhang, X.J. (2014). A Series of Lanthanide(III) Coordination Polymers Derived via in Situ Hydrothermal Decarboxylation of Quinoline-2,3dicarboxylic Acid. Inorganic Chemistry Communications, 39: 56-60.

[26] Xu, B., Zhang, T., Zhang, L., Li, C.C. (2014). Structures and Properties of Coordination Polymers Based on 5-Nitroisophthalic Acid and N,N'-Bis(4-pyridyl-methyl)piperazine. Zeitschrift fur Anorganische und Allgemeine Chemie, 640: 2503-2507.

[27] Ashiry, K.O., Zhao, Y.H., Shao, K.Z., Su, Z.M., Xu, G.J. (2009). Syntheses and Characterizations of Three Coordination Polymers Based on Dipyridylbenzoates and 1,4Bezenedicarboxylate. Polyhedron, 28: 975979.

[28] Tai, X.S., Zhao, W.H. (2015). Synthesis, Crystal Structure, and Antibacterial Activity of Magnesium(II) Coordination Polymers Formed by Hydrogen Bonding. Research on Chemical Intermediates, 41: 3471-3478.

[29] Tai, X.S., Wang, X. (2017). Synthesis, Structural Characterization and Antitumor Activity of a Ca(II) Coordination Polymer Based on 4-Formyl-1,3-benzenedisulfonate-2-furoic Acid Hydrazide Ligands. Crystallography Reports, 62: 242-245.

[30] Sheldrick, G.M. (2008). A Short History of SHELX. Acta Crystallographica, A64: 112122 